\title{
THE PLACE OF FISH PRODUCTION IN A PROGRAM OF MULTIPLE WATER USE
}

CarL L. HubBs, Chairman University of Michigan

\author{
H. L. Shantz \\ U. S. Forest Service \\ J. N. DarLing \\ National Wildlife Federation \\ A. H. WIGBE \\ Tennessee Valley Authority \\ ELmber Hragins \\ TI. S. Fish and Wildlife Service
}

KEIN NETH A. RED

Izaak Walton League of America

Frank B. Wirk

Oregon Game Commission

JaMus R. SHMON

Wyoming Game and Fish Commission

A. D. Aldprich

Oklahoma Game and Fish Commission

\section{The Chairman :}

Water has always been of prime significance in making the earth habitable, as we quickly appreciate in crossing the arid west. Water use ranks with land use as a factor in human existence and civilization. It supplies us with a considerable proportion of our food and makes possible all food production; if we include soil water in our consideration. On water we transport ourselves and our goods. Through water power developed by damming streams we make use of the energy of the sun, and we will be increasingly dependent on this source of power as we deplete the supplies of coal and oil which have stored the energy of bygone sunlight. Centers of population and of industry have been made possible by the use of water to carry off waste products, and by the storage of water to make it available during seasons or years of drought. In similar ways drainage and storage have made agriculture possible in many regions. Recreational, esthetic and health values of water are each of prime importance, though some members of this Society minimize its health-giving powers.

Multiple water use now exists, but the use is seldom as wise or as efficacious as it should be. Fishery interests in particular have been neglected, and fish experts have often not had, or have not fully taken, the opportunity of representation on planning boards and administrative agencies concerned with water use.

When under control, water, considering its manifold uses, is man's most indispensable friend. When out of control, as in raging floods, excessive drainage, unwise impoundment, gross pollution, water is a destructive scourge.

We were asked in these panel discussions to adhere more or less to the American Fish Policy. Before the discussion opens I will read two sections of the policy which pertain to multiple water use. Section II (1) reads : 


\begin{abstract}
"The federal, dominion, state, provincial, and regional planning boards should consider the fishery resources as a very important element of national wealth and not as a minor incident in the development of power, flood control, drainage, irrigation, reclamation, and recreational projects, as has been done in the past. The planning boards should recognize wherever possible the principle of prior right for the fisheries. Only when a proposed water development exceeds in public value the fisheries resource, should the latter be sacrificed, in which case the fishery interests should be compensated fully for their losses. The fisheries should be given equality of representation on all planning agencies at all times and should be represented by qualified persons from the state, provincial, and federal agencies involved.",
\end{abstract}

Note that it says "state, provincial and federal." One other section is significant in our present discussion :

"Since soil erosion, reforestation, drainage, flood control, water restoration, and impoundment of waters are now recognized as tremendously important factors in fish production, the closest contact should be maintained between fishery officials and the agencies responsible for these various activities."

I have tried to outline this topic in such a way as to give a fairly rounded discussion of a very large subject. I am going to ask several persons in the audience to present informal remarks, avoiding detail, so we may have the benefit of their knowledge and experience as they bear upon this problem of multiple water use.

\title{
DR. Shantz:
}

The Forest Service is tremendously interested in the waters of the National forest areas, since we are held responsible by Congress for the management of the forest lands. Our responsibility is very great in respect to the waters and lakes fed by those lands. No doubt the richness of a body of water is largely measured in terms of richness of the lands which feed them. To that extent anything that is done in the management of forest lands is reflected at once in the charcter of the waters which drain those areas.

We are anxious above all to see the waters of the lakes and streams made a productive part of our National resource. To that end we have worked with the State game and fish departments and with the Fish and Wildlife Service to increase the productivity of these waters and keep them in as good condition as possible. The work with the States has depended largely on what the State wished us to do. Wherever they wished us to help we have tried to do so, and wherever they felt they could better do the job themselves we have had little choice other than to allow them to do it. However, there are two or three problems in which we are very definitely interested. In the national forests there are uses for our waters. There are reservoirs which of necessity fluctuate in level. There are irrigation reservoirs that likewise are subject to great fluctuations. In some places we have been able to go back into the upper reaches of these great reser- 
voirs and to establish permanent level areas by constructing small dams, in order to improve not only the conditions for fish but the conditions for wildlife in general. We have also worked closely with the Federal Power Commission in order to prevent power developments from closing up streams. For some reason or other the last drop of water is more valuable than the first, and there is a tendency in damming rivers not to allow sufficient spill and the cost of keeping the streams alive is difficult to justify because of the high value of the water when measured in terms of electric power.

There are many areas far in the back country where fishing and even stocking is difficult. In most of these areas we have been able to aid the State departments by carrying stock for these lakes and streams. Of every 100 people who visit the forests, 20 come for fishing and 8 for hunting. Four and a half million people came to the forests last year for these purposes.

It is evident also that we have tremendous problems which touch upon the problems of fertilization now being studied by Swingle and Smith of Alabama. The Forest Service has jurisdiction of many large parcels of land which were not specially suited for other purposes. In these areas there is a population of dependent people, so that we have inherited an immense social and economic responsibility. There are great areas where the production of food in small ponds and lakes is a vital necessity. Many people in those areas are undernourished and cannot easily produce sufficient food by raising domestic animals. We feel that there is an opportunity to do something for thousands of people who otherwise would continue with a thoroughly unbalanced diet, by increasing the fish production of ponds and the production of game on these forest areas.

\section{Mr. Darling:}

You will be glad to know that I am under doctor's orders to make no speeches. I look all right on the outside but I have a lot of crutches on the inside.

I know of no more important subject in the United States today than the multiple use of waters. There is a great battle to fight. I am here as a listener. I am out of the picture temporarily, but I am glad to be here and to see again so many of my old friends.

\section{DR. WIEBE :}

I believe we fishery workers and conservationists must realize that we face a period in which there will be considerable hydro-electric development. What is going to be our position? Are we going to say that there should not be any, or are we going to accept the program in the main, try to keep it under control, and make the best of it? The reservoirs created by the Tennessee Valley Authority are ex- 
tremely popular within the region in which they are located. I am satisfied that if a poll were taken today or any other day as to whether we should retain the reservoirs or should go back to the original Tennessee River-some people have said we have ruined the Tennessee River-the vote would be overwhelmingly in favor of retaining the reservoir.

It is estimated that the recreational business associated with the Norris Reservoir is in the neighborhood of a million and a quarter dollars per year. Formerly there was a very small river, with a flow of $300-500$ second-feet. Now we have a reservoir with a capacity of 32,000 acres; it is all nice clear water, and people can have a lot of fun and see a lot of pretty scenery. If you should visit and see all the automobiles from Kentucky, Ohio, Michigan and Minnesota, where many natural lakes occur, you would appreciate that a little more.

The water-use program of the Tennessee Valley Authority has two distinct phases. One is to retain the water on the land. For that reason the Authority is engaged in an extensive program of fire control, soil-erosion control, and reforestation. I am convinced that we are engaged in the best stream improvement work in the country. If we can regulate the run-off, stream flows will be more constant and there will be a more favorable environment for fish.

The Tennessee Valley Authority Act (16 U. S. C. 831) states certain objectives specifically. Fish and game are not mentioned. The objectives are : Flood control, navigation, power production and $\mathrm{Na}$ tional defense. While fish and game are not mentioned specifically, by implication in Section 22 of the act, fishery and wildlife work, agricultural improvement, forestry and other related activities are permissible.

Flood control, then, is the first objective. That is something people will not quarrel over. We are in favor of flood control, and in that regard it should be emphasized that flood control and navigation have prior rights over power production in the use of water. This priority is borne out by the fact that when the storage reservoir gets low but still contains considerable water, steam plants are set up to generate power, and the impounded water is routed through to maintain a navigable channel. Again, in times of incipient floods, the reservoirs are lowered in anticipation of the floods. Such is the priority that flood control and navigation have over power production.

With regard to the fishery work in the multiple-use program, as I have said, it is not stated specifically in the act as an objective of the Authority. Those of us who are engaged in fishery work are in a somewhat peculiar position; we represent a tiny appendage on an enormous organism or animal. Therefore our problem has not only been the fisheries but also to sell the fishery problem to the Authority. There is scarcely an engineer in the Authority who does not respect the fishery workers and their program. Our work has shown that, although the primary objectives are flood control, navigation, power 
and national defense, we can develop very excellent fishing. Over a million fishing trips occurred on our four reservoirs in Alabama last summer and more than a million pounds of fish were taken by commercial fishermen. Three and one-half million pounds of fish were taken by sport fishermen.

There is no indication that these reservoirs eventually will become barren. The Wilson Reservoir, which is 16 years old, supports fishing as good as the reservoirs that are 2 to 5 years old; in fact better. It is of extreme significance to good fishing that the fish have a chance to be born. During the spawning season we ask the Water-Control Board to stabilize water levels, and they do it, on the large reservoirs. Some of the smaller units are so small and have so much head that stabilization is not easily achieved.

Good fishing can be had even if the water is used to generate electricity. Power generation doesn't seem to make much difference to the fish. We are fortunate in one respect; we do not have much pollution. In fact, sometimes I wish we had a couple of good sized cities on Norris Reservoir to contribute some fertilizer. In this program of hydro-electric development involving a single reservoir and a certain community depending on it for power, that reservoir is going to fluctuate no matter how many resolutions this meeting may pass urging a contrary policy. When an entire river system is harnessed as we are doing at the Tennessee River, and where a series of reservoirs is established, the water runs from one reservoir into another. Unless the load is unusually heavy, power is generated here today and there tomorrow. Properly developed and properly regulated I believe that multiple use of the water, even if largely due to the necessities of power, can still produce a great deal of fishing. People don't have to believe a word I am saying-come down and see for yourselves; you are welcome!

\section{Mr. Higains :}

Dr. Wiebe has referred to the fortunate circumstances which have produced excellent fishing in the Tennessee Valley and has demonstrated clearly the advantages that have resulted from the program of multiple use of water in that area. We have quite a different problem in the Pacific Northwest where anadromous fishes are concerned. Dams can be of no benefit whatever to anadromous fishes because their spawning grounds are often above the obstructions and the production of fish life within the reservoirs is relatively unimportant. I can describe to you briefly four or five situations in the Pacific Northwest which, arranged in chronological order, indicate a trend which I regard as one of the fortunate circumstances among the many unfortunate ones involved.

You all know something of the history of the Bonneville Dam on the 
Columbia River-at that time one of the greatest engineering achievements and one that obstructed the largest run of anadromous fishes. The money was provided and the Corps of Engineers of the U. S. Army began their plans for construction long before there was any thought of protecting the fishery resources. Before construction began, however, and through the insistence of fishery interests, the former Bureau of Fisheries was called into the picture and one of our biologists was detailed to begin a study of the protection of the fish of the Columbia River.

Construction was to begin within less than a year of the time the surveys and studies were undertaken, consequently there was insufficient time for a complete solution of the problems of fish protection. Starting from scratch, Mr. Harlan B. Holmes, our biologist, and Mr. Henry F. Blood, the engineer from Portland; Oregon, devised between them a general program of fish-ladder construction to provide access to the upper spawning grounds of the Columbia River. The devices involved all the good practices in fish-ladder construction as then known, and a number of novel devices were used which have proved themselves to be very effective. The Army engineering staff, of course, contributed very largely to the detailed designs. Before any amount of concrete was poured provision was made in the foundation of the dam for a series of four large ladders 40 feet wide. Two sets of duplicate fish locks or so-called elevators were provided also.

That effort, carried through in such haste, has produced satisfactory results so far as up-stream migration is concerned. The runs of salmon have passed the Bonneville Dam with no interference whatever. There has been no accumulation of fish below the dam; once they enter the fishways they pass over very rapidly. One fortunate circumstance is that counting weirs were established in the heads of each of these passages and we now for the first time are able to keep books on the salmon resources of the Columbia River, knowing as we do the escapement past the greater part of the commercial fishery to the spawning ground.

The next major problem encountered was concerned with the construction of the Grand Coulee Dam. There again the dam was authorized and the money provided long before studies of fish protection were undertaken. Before the U. S. Bureau of Reclamation began its construction program, money was allotted to enable fishery biologists to make preliminary surveys, this time for a period of a year, and a considerable amount of valuable information regarding the protection problem was amassed.

The Bureau of Reclamation was very sympathetic to the problem of fish protection. They provided a liberal fund for the continuation, for a period of perhaps 8 years, of a system of transference of the main runs of salmon obstructed by the Grand Coulee Dam to major tributaries below, between the Grand Coulee Dam and the Rock Island Dam, where the fish could be eaught on their upstream migra- 
tion. There is now in progress an elaborate program of transference, catching the upstream migrants, hauling them in "air-conditioned trucks," as the newspaper men like to call them, and depositing them either in favorable spawning streams below the Grand Coulee Dam or transferring them to the hatchery at Leavenworth, Washington, where the usual fish-cultural practices are followed. That program, with all its difficulties of handling great numbers of very large fish in rather shallow and fairly warm water, with attendant disease, which is a headache to the fish-culturist, is developing in a promising way.

Next we have a program of water development in the Central Valley of California. Already under construction and well on toward completion is the Shasta Dam on the Sacramento River, which will prevent the access of considerable runs of salmon to their major spawning grounds. Here we were less fortunate in finding the right solution, such as the transference of the runs to new spawning areas, because the Central Valley is so arid and the streams so intermittent and so small that adequate spawning grounds in tributaries below the dam simply do not exist. The only hope, therefore, of maintaining that considerable run will be an elaborate system of artificial propagation to supplement whatever natural spawning is still possible.

Below the Shasta Dam three racks will be placed in the main Sacramento River, where the spring run of salmon as it approaches the dam, will be divided into groups and where we believe there will be a considerable amount of natural spawning. The remainder of the spring run and most of the fall run will have to be transferred by truck, by much the same process as is used in the Grand Coulee program, to hatcheries, or placed in one of the two tributaries below the dam that have enough water to support them. I must admit frankly that the prospects of maintaining that considerable run of salmon are far less bright than they are in the case of the Grand Coulee salvage program.

The construction of the Shasta Dam also is being undertaken by the U. S. Bureau of Reclamation. In the early stages money was provided for extensive fishing surveys which have been under way now for nearly 3 years. Further studies will be carried on for the next several years in relation to the problems of the other parts of the Central Valley program, particularly the protection of the fish from the pumping plant which will be established on the lower Sacramento River to supply water to the lower San Joaquin River. A cross channel will be built to satisfy the demands of irrigation in the lower San Joaquin River. These problems are still to be faced, but the Bureau of Reclamation has shown, as I have said before, a very sympathetic attitude and is providing money.

We still have before us the problem of flood control on the Willamette River, which is perhaps the worst headache of all, because below the four large dams still to be built there are so few tributaries or spawning areas that can be made available to the fish that in all likelihood the Willamette salmon run can be continued only through artifi- 
cial propagation. The War Department, which is responsible for the development, is providing funds for surveys and further studies.

In another field the Bureau of Reclamation has shown an increasing interest in fish protection, namely in the screening of irrigation ditches. Starting some 7 or 8 years ago, P. W. A. funds were provided the Fish and Wildlife Service to enable it to-construct a number of very large screens in major Federal irrigation projects. A rotary screen has been developed to a very satisfactory state of perfection. Five very large screens are operating in canals that are big enough to float a steamship. The screens are perhaps doing more for the protection of the salmon runs in the Columbia River Basin than any other single thing I can think of, because in the unscreened ditches tremendous quantities of downstream migrants went to their death.

A fortunate trend in all these cases is the growth of appreciation of fishery problems on the part of other public and Federal agencies. At Bonneville Dam, as I have said, construction was about to begin before problems affecting the fisheries were considered. In these other cases conservation of the fish supply has been given every consideration, and earlier consideration than in the previous project. Finally, there is the recognition by the Bureau of Reclamation of the priority of fish rights, even priority over irrigation, which is rated so high, by building from their own funds, on their own initiative, and with their own engineering talent, a very large fish screen in the Rosa diversion on the Yakima River, the last large reclamation project that has been completed. That screen comes into operation this year and undoubtedly will prove very effective.

With this growth of interest, then, on the part of Federal construction agencies in the conservation program $\mathrm{I}$ believe we are making progress; I believe that the problems of multiple water use will be solved and that the entire program of full utilization of our resources will be facilitated.

\section{The Chairman :}

I know of another gentleman who would have enjoyed the opportunity to speak on our topic of the multiple use of water, but he is unable to be here. I wish to quote two paragraphs from his letter, however, in which Mr. William I. Finley expresses his views :

" The fish resources of the Northwest are very valuable, but not properly protected because of the lack of necessary laws. The spring chinook salmon are of the greatest importance but have been going down steadily for many years in the Columbia River. The laws of Washington are more protective than the Oregon laws. The demand for more dams on the Columbia and Willamette Rivers is destructive, but the promoters claim the salmon will be maintained by artificial propagation, which is not scientifically correct.

"At present there is a flood-control bill in Congress which may be passed before your meeting is held, allotting more money for these high Willamette dams. It seems to me that the American Fisheries Society should fight for fish protection." 


\section{Mr. REID :}

I heartily concur in the views Mr. Finley has expressed in his letter. The problem of proper protection for the fisheries from the tremendous hazards imposed by power, irrigation, and navigation developments is difficult to solve. The fisheries commonly have received only the "hindmost." It is encouraging to hear of the progress reported in this field by Mr. Higgins, and I know that some improvements have been made. But we still have to face the unpleasant fact that in large construction programs, if the fisheries receive any consideration, it is largely a gesture. Not only the fisheries suffer but the broad public rights in water, including the right of American citizens to enjoy our aquatic resources, receive little consideration. Inalienable public rights are subordinated to the special-interest uses of public waters. We may as well face the facts now.

I was greatly interested in Dr. Wiebe's comments on the T. V. A. program. I had the pleasure of spending a day with him and some of his colleagues last year and saw some of the reservoirs. When we consider the place of the fisheries in programs involving the multiple use of water, much depends on where the dams are constructed. Did the river blockaded by these dams have more aquatic values to begin with or did the dams provide better possibilities for productive fisheries? In the case of the Tennessee River, it was comparatively low in productivity. In sport fishing I believe the dams on the T. V. A. are, as Dr. Wiebe has said, on the asset side of the ledger. A more specific case is Boulder Dam on the Colorado River. It was a river too thin to plow and to thick to drink, a river that was practically worthless from standpoint of aquatic life and recreation. Boulder Dam has created more fishing on the upstream side of the dam for black bass and on the downstream side for rainbow trout. I had the pleasure of fishing both during the 2 days I was there last December. I wish to point out to you that the fishing at Boulder Dam, both above the dam and below, was merely a happenstance. If the Colorado River had been a good fishing stream and the dams, having regard to the purposes for which they were built, ruined it, it would have been ruined without the batting of an eye.

Let me give you another example. The Gunnison River in Colorado was a famous trout stream. I fished it for 20 years, off and on. A dam had been built by the Bureau of Reclamation on the Taylor River, one of the head forks of the Gunnison, to supply water users far down the Gunnison Valley. When I was there in late June the river appeared as if it were at the mid-August stage. The reason was that the spillways in the dam had been closed to store up water for irrigation. Then I went on an inspection trip for 5 days and came back at the end of the week of July 4. The river was high and dirty. During the week of July 4 the river was lined with fishermen, the whole way up the Gunnison, and I am sure I saw at least two or three hundred fishermen and not a tight line. On the opening day six boys 
had come to the hotel to spend a week fishing. A day and a half later they left in disgust because of the utter disregard for anything except so many acre-feet of water for irrigation. The water users association had called for water, and up went the gates of the Taylor Dam. For many people who visited the river for their only vacation the fishing was ruined and they went away disgusted. That is not good water management; it is not management in the public interest. It is that sort of narrow-minded, selfish, inconsiderate water management that we have to get changed.

That undesirable condition could have been corrected; it need not have happened. Of all the weeks in the whole 52 of the year to run sulky water down an outstanding trout river, the week of July 4 was obviously the worst. Furthermore it could have been done gradually if any had to go down that week. But it was not done, simply because there was no consideration for fishing. The proper point of view in connection with these water problems is consideration of all values, not just consideration of one or two or three utilitarian uses that involve private exploitation of water, whether done with Federal money or with private funds. It is a problem simply of social behaviour. Consideration of the rights of others will solve 90 per cent of these problems.

I made it my business a few years ago to find out why hydro-electric power and reclamation always got the ringside seat on these water developments, and why not only the fisheries but the whole interest of the public in the use and enjoyment of water were shoved aside. I found out that the reclamation lobby had been sufficiently powerful to get written into the Reclamation Act a provision declaring reclamation to be a priority use of the water, taking precedence over the use of the water by the public. The same applies to hydro-powe: development through the Geological Survey and the Federal Power Commission. There is something for us all to think about-an amendment to the Reclamation Act which gives preferential rights to hydroelectric power development over public uses of water. We have not attempted it this year, for reasons which are obvious to all of you; nevertheless there is the basic difficulty in this whole water use program.

I was glad to hear from Mr. Higgins that the Bureau of Reclamation is becoming more considerate in this matter. No doubt he is correct, but the Lord knows there is room for much improvement. The Fish and Wildlife Service and the Reclamation Service are brothers and sisters in the same department and naturally they have to be careful what they say about each other. I was in Washington about a year ago trying to dig into this thing and I saw Secretary Ickes. He suggested that I see Commissioner Page, which I did. I presented the problem of screening of irrigation ditches and the necessity for doing something about it at the source. His reply to me was about like this: Most of the western States, practically all of them 
in fact, have laws requiring the screening of irrigation ditches but they do not enforce them against the rangers, therefore why should we bother? He said: "I don't believe that we could get our water users who pay for these dams" - and I made a mental reservation as to whether or not they actually do pay for them-" "to go to the additional expense of putting in screens." I said: "My God, man, if Uncle Sam's Federal bureaus cannot set the example on this thing, how in the world can you expect any improvement elsewhere?" In other words, I put it squarely up to the Bureau of Reclamation that we believed it was their responsibility to provide these screens in connection with every dam-to provide for their construction and their continuous operation as an integral part of the engineering plans and as a condition. of approval of any dam project. Although we have taken our stand on that sort of thing and keep reiterating it all the time, we still continue to get the hindmost.

Then there is the question of flood control. Control of floods is excellent, if it is honest, but I want to say frankly that about 90 per cent of the so-called flood control is a blind for hydro power, for irrigation, for spending large sums of Federal money in a community for political purposes. If anybody wants to argue with me about that, I will be delighted. We might well quit "pulling our punches" and get down to "brass tacks" on this thing. I heard Glen Egerton at a conference in Wilson, West Virginia, make a statement which gave me a better opinion of at least some Army engineers than I had before. As I recall his statement, it was this: "When we are honest with ourselves and get down to the bottom of this flood problem, about 90 per cent of flood damage is the result of man's damn foolishness in building roads, railroads, houses, factories, and what not, on land that plainly belongs to the river. When the evidence that the river had used that land for flood purposes is plainly visible, you can be darned sure the river will again flood that land. It would be much more sensible and economical to retire from human occupancy and use of many of our perennially flooded lands and give them back to the river for flood purposes." I wish some of the Army engineers would have the courage to get up on their hind feet and enunciate such a sound principle.

I wish I had time to go into this flood control business thoroughly. It is certainly being used as a blind and subterfuge for all sorts of "skulduggery". It is being put in as a measure of National Defense. I am getting so allergic to that National Defense argument that comes up in every bill in Congress.

In considering this problem of multiple water use, the important thing is to bring in biologists and scientists at the outset and not for a post mortem as in the past. The "Coordination Act" of $1934^{1}$ provides for calling in the former Bureau of Fisheries and the former Bureau of Biological Survey, now the Fish and Wildlife Service, and con-

'Act of March 10, 1934, 48 Stat. 401-402; 16 U.S.C. 661-666. 
sulting them in advance. But that is not quite strong enough. The other more favored agencies have ignored the fish and wildlife aspects of the projects. They have made their plans, begun construction, and then if they felt like it they would tell the Fish and Wildlife Service what was going on. Let me say that these remarks are not intended to criticize the Fish and Wildlife Service or the Forest Service, but I do have some criticism of some of the other bureaus.

What do we have in the way of pending legislation at the present time? One can do no more on an occasion such as this than cover the high points of the legislation that is now before Congress. Practically every one of the bills is called "National Defense"; and many have no more valid connection with National Defense than with any silly project you could imagine. It is almost sabotaging the National Defense program to divert tremendous amounts of money, manpower and material into engineering works that ought to go into the production of planes, guns, and ammunition. The pending flood control bill (H.R. 4911) is another pork-barrel measure. It is an excuse for spending $\$ 275,000,000$, which, converted into modern fighting planes and dive bombers would give us a fleet of 3,809 . Then there is the flood control bill to establish an Arkansas Valley Authority patterned after the T.V.A. In the Ozarks are splendid smallmouth black bass streams that will become carp and buffalo streams after these dams go in. I am going down there before this hydromania gets into operation in order to have something to remember in my old age. This country is tending toward a land in which every rapid and fall will be converted into a gigantic concrete structure for generating hydro power and for socalled flood control.

Representative Rankin of Mississippi introduced a bill in Congress on August 11, seeking to divide the whole of the United States into socalled conservation authorities. It includes the A.V.A., the T.V.A. and six others. Such a bill, if the motive back of it were sound from the standpoint of conservation of natural resources, might conceivably be a good thing, but it is very obvious that this bill is motivated by the same old thing - some people in Washington call it public water conservation, but we believe it to be the rankest sort of political water exploitation. In other words, the purposes of the Rankin Bill are hydro power, flood control, navigation and irrigation; and incidentally, the bill states that among the duties of the so-called conservation authorities shall be the encouragement of the widest possible use of hydro-electric energy and the fullest development of our water resources and the encouragement of the widest possible regulation of our public lands by both irrigation and drainage. Think that over; they call it conservation! The Rankin Bill is called a National Defense measure, in spite of the fact that it will be 5 to 7 years before many of the dams will be completed.

What of the future? I had great hopes for the National Resources Planning Board. A reading of the preamble to their voluminous 
report and recommendations made me feel good; it sounded well-it could not have been better if I had written it myself. However, I understand that some of the Federal agencies that appreciate the value of our natural resources have spent hours, days and weeks of work getting out reports and recommendations which apparently have gone into the waste-paper basket. I want to give you just a few of the high points of that report and its recommendations.

Here are a few highlights of the recommendation for outright appropriations for Federal construction projects. For the Army engineers-and not for defense purposes-for inland water navigation, $\$ 1,690,000,000$. For the Bureau of Reclamation, $\$ 1,230,000,000$. For the Fish and Wildlife Service, $\$ 1,230,000$, which is exactly onethousandth of the amount recommended for the Bureau of Reclamation and one fifteen-hundredth of the amount recommended for the Army engineers. Then we come to the Soil Conservation Service, and we might expect it would be on top. No, only $\$ 441,000$ is recommended for the Soil Conservation Service, which is one-third of that recommended for the Fish and Wildlife Service and one threethousandth of that recommended for the Bureau of Reclamation. I see Dr. Shantz is writing some notes; let me tell him something about the Forest Service. At first glance the Forest Service appropriation looks like $\$ 842,000,000$. It is in three categories : (1) Forest highways, (2) forest development, roads and trails, and (3) wildlife conservation. The first two categories are to be allotted $\$ 841,500,000$ of the $\$ 842,000,000$ recommended for the Forest Service.

I sincerely believe that the most serious conservation problem before the American Fisheries Society and the American public is this, that the disease of hydromania that your Government has apparently contracted from the power companies in its more virulent form, blinds the victim to all values in the running stream except so many kilowatthours going to waste. You and I see other values in a stream, but not the fellow who is afflicted with hydromania.

Lest anyone here have the conception that $I$ have any concern about who shall generate hydro power and that I am in any way fighting for private interests, it is a matter of record and can be verified by people from West Virginia that in 1930 I was the sole protestant when I wrote the Izaak Walton League protesting against damage to some of my favorite trout streams in West Virginia. Eighty-six miles of them were dried up by the application of the West Virginia Power Company, whose president is a cousin of mine. I hold no brief for the private power company, which is one of the worst disturbers of aquatic values, and it is small consolation to me and to you if it is Uncle Sam instead of a private corporation that ruins your river and my river. All we need for a solution of this thing, as I said before, is consideration of all values in advance of the engineering, and practice of that simple rule of good social behavior-consideration of the rights of others. 
Mr. WIRE:

If Kenneth Reid had not given us as good a talk as he did, I do not know that I would have dared to get up here, because I would have said something I should not have said. My friend Bill Finley, if he were here, would probably say in a much more vociferous manner what I wish to say.

I do not want anybody to consider my remarks as derogatory of the Fish and Wildlife Service nor of the work of the former Bureau of Fisheries. They were told: "Here is a dam; now you fellows do the best you can with it." When the construction of the Bonneville Dam was undertaken, a certain major of the Army engineers came out there and very inadvisedly made the remark that he was sent there to build a dam and "to hell with the fishing". He was removed very soon after he made that remark, because he found it was very unpopular in Oregon and Washington as well as in other places in the United States. The Fish and Wildlife Service through its biologist and engineer Harlan B. Holmes, got busy and we went through that fight. Fish ladders were put over Bonneville Dam to permit passage of the run of anadromous fish. I cannot say that for the Grand Coulee Dam. Mr. Higgins expressed the difficulty mildly when he said it was a headache. I predict that the ten-million dollar salmon industry on the Columbia River is going to be definitely affected in the cycles to come.

These dams are already built, but we have the Willamette Valley Project that $\mathrm{Mr}$. Reid and Mr. Higgins told you about. A dam 325 feet high is contemplated on the Santiam, one of the tributaries of the Willamette River. The Willamette River is the only important tributary of the Columbia River below Bonneville Dam where there is a valuable run of anadromous fish. The large run of spring chinook salmon, which is the most valuable run in the Columbia River, spawn in the Willamette River and its tributaries. The Willamette Valley flood-control project is the bunk! It is not needed for flood control. If a sum of about $\$ 10,000,000$ had been appropriated for a revetment or dike along the Willamette River the problem would have been solved; but no, they want to build the dams. In the Willamette Valley we don't need irrigation, we don't need flood control, we don't need navigation.

Another high dam is projected on the McKenzie River, one of the finest streams for anadromous fishes and the spring chinook salmon in the entire water system. The dams will all be too high for any fish ladders, and the only way runs can be maintained, as you have been told, is through artificial propagation. We believe in artificial propagation, but we believe it is only a means to an end. We are also very strong in our ideas regarding natural propagation. Many of the dams will be so far downstream that the spring run of chinook salmon will reach them in June or July. If the fish are held below the dams and the water temperatures increase in the summer, many of the fish will 
die before they reach the spawning stage. Production of young will be a failure.

I wish that a resolution could be passed by this Society opposing the Willamette Valley Project. The high dams have not been built, only one or two low dams that do not affect the runs of anadromous fish and which we did not particularly oppose. We do not want these dams. As I told you before, there is not a single excuse for building them except the spending of Federal funds.

\section{Mr. Simon :}

I will give you a few examples of our use of irrigation reservoirs in Wyoming and also the stock-watering reservoirs in the State. Our use of such bodies of water is typical of the use given them by other inland western States.

There are four types of reservoirs: (1) The irrigation reservoir or the storage reservoir; (2) the control or regulatory reservoir; (3) the stock-watering reservoir, of which a few hundred have been built in the past few years; and (4) the power reservoir, which is used in combination with the irrigation reservoir.

One of our most difficult problems is in the use of any irrigation reservoir for sport-fishing purposes. We know that the loss of fish due to irrigation greatly exceeds the catch each year by fishermen. We feel that in the planning and construction of these reservoirs aquatic values have been ignored in almost every instance. For example, a new reservoir completed this summer was supplied with water from the Grey Bull River. As the water was let out of the reservoir, for a considerable distance it cut through a clay bank. Whether or not the reservoir meant anything as a fishing locality, the fact that hundreds of tons of silt were washed into the Grey Bull River over a distance of 30 miles makes its value negative to those of us who look upon the river as potentially of greater value than the reservoir itself.

Another difficulty we face constantly is the fact that applications for fish continue to flow in in enormous numbers; applications for reservoirs that we are satisfied are not suitable for fish. It becomes the duty of the State administrators to refuse fish to the public under those circumstances, but these fish have been offered by the Federal agency which raised them. This difficulty could be overcome if the system of application for distribution of Federal fish were dispensed with. Administrators know that it is a difficult thing to have to refuse fish, particularly when the people think they have the fish coming to them simply because they have the water, although they know nothing about its biological value.

We are attempting to screen irrigation ditches on a small scale. With 5,000 reservoirs in the State and an equal number of head gates diverting water out of trout streams the problem is enormous for a State. Legislation passed at the last session of the Wyoming legisla- 
ture gave to our department the responsibility for the installation of fish screens, simply because it was the only way we could insure screening of irrigation ditches.

In considering the biological values of reservoirs and irrigation works as a whole, let me point out ways in which there is a loss of fish through irrigation works. One is due to inadequate control of the water as it leaves the reservoir. Another concerns the head gates at reservoirs, or on streams below the reservoirs, or on streams that have no reservoirs on them, in all of which the danger arises through the complete drawdown of irrigation reservoirs containing fish. We have not stocked these reservoirs in which there is a complete drawdown, but since most of them are situated on live streams there is a constant drift of fish into each reservoir, and when the need for irrigation water is great there is no compunction whatever about draining that particular body of water completely. This procedure results in enormous losses of fish.

We have two types of stock-water reservoirs, the live one, and the temporary one. Most of our stream survey work in the last 2 years has been on reservoirs of both types. First we tried to select from the great number of irrigation reservoirs and stock-water reservoirs those which can justifiably be stocked with fish. The live stock-water reservoirs are sometimes good, particularly when they are located below the permanent spring stream run. The temporary live stock reservoirs, however, cannot be stocked because they may be full for 1 or 2 years, but in dry seasons they will be drained before the fish with which they are stocked can be utilized.

Many of the irrigation reservoirs in Wyoming are modified permanent lakes from which only a certain amount of water can be drained off the top. When the old lake on which the reservoir was built was deep enough, many are excellent for fish rearing, and some support excellent fishing today. In the reservoirs which can be drained we dare not plant fish. Agencies responsible for construction of reservoirs are prone to allay the public mind by promising good fishing wherever they create a body of water. That has resulted in ill-feeling on the part of people who see a body of water and expect to have fishing from it. When the State will not or cannot supply fishing the public become critical and our position is difficult, to say the least.

\section{The Chairman :}

I wish we had time to call on Mr. Bode of Missouri and Mr. Warfel of New Hampshire to express their views concerning this conflict of interests, particularly in connection with the construction of dams. There are many other aspects of multiple water use but in this brief program we have not had an opportunity to discuss them. I do not want to have any of you feel that the problem is narrow. I will briefly 
mention a few of these other points with respect to multiple water use before I call on one more speaker for the morning.

We have a very important problem of fish production in recreational lakes-lakes produced for fishing, boating and swimming. Mr. E. B. Speaker could tell us about those constructed in Iowa. Mr. A. R. Shields has already discussed that topic for Tennessee in another panel discussion. We would like to hear from Illinois, where these recreational lakes are being constructed.

I agree with Dr. R. W. Eschmeyer in his statement that the greatest fish increase that we can obtain is through increase in the acreage of water in lakes that are properly managed for fish production. I wish we had an opportunity to go into the question of fish production on farm fish ponds of various sorts. Dr. H. S. Swingle discussed this subject in another panel at this meeting. I will not ask him to repeat his remarks, for I am sure you remember what he said and will include that in the concept of multiple water use. The Soil Conservation Service, as he mentioned, is considering the possibility of fish production in the small multiple-control dams.

Conflicts of interest have been mentioned. There is the question of pollution; Dr. H. J. Deason was to give his views on that, but there is not time. Reference has been made by Dr. Clarence Tarzwell to mosquito-control activities and to a cooperative investigation made in this regard with the Tennessee Valley Authority. We should also hear something of the agricultural use and misuse of water in relation to erosion and silting, a most important cause of depletion of our fishes.

\section{Mr. ALDRICH :}

Some few years ago we gave a report of a specific instance of the multiple use of reservoirs, particularly for municipal water supplies. In most of the Middlewest, particularly through Oklahoma, the reservoirs are used for municipal water supplies.

Perhaps the first important thing in eonnection with these municipal water supplies is the fact that we have a State law in Oklahoma which provides that all funds collected on these municipal lakes or reservoirs shall be used for fish propagation or protection. The law also provides that the municipalities may make their own regulations pertaining to fishing on the reservoirs. That is very fortunate. Of course the eity cannot increase the State bag limit but it may further restrict the State regulations. The city cannot override the State law, but our laws are quite generous so that it is usually a matter of further restriction rather than of liberalization.

I wish we could practice fertilization in many of the reservoirs, but of course we have to work in cooperation with the State health department and we cannot recommend fertilization of waters in the municipal reservoirs when the waters are chlorinated and filtered. The problem of municipal lakes in Oklahoma consists of making a survey 
to determine the existing conditions and then to conduct an inquiry relative to each lake in order to assure the fullest use of the water under the conditions for which it exists. At Tulsa we have never found any correlation between the intensity of fishing and the $B$. Coli count of our municipal waters, which never have suffered any noticeable pollution. We believe that when the regulations are properly designed and people respect the privilege of using these lakes for angling and other recreational uses they enjoy greater benefits than if they were allowed promiscuously to use the stream and ignore sanitation.

We have found that it is most important to give assistance to anglers. By and large, the majority of the fishermen do not know how and where or what to fish for when they enter one of these municipal areas. The surveys should be sufficiently detailed on each one of the reservoir lakes to provide information desired by the anglers. Guides, who actually know the lakes, what to fish, what bait to use, and what particular spot to fish in, are available. We have prepared booklets of different kinds, and we have an aerial map of the lake showing the various fishing holes. We even go so far as to stop and visit anglers who are not familiar with the lake and tell them where to go. We give all these services to the anglers, and that is made possible throughout many of these municipal reservoirs in Oklahoma because all the funds collected on these reservoirs must go into this kind of work. I think at least all the larger municipal lakes do have quite substantial funds for carrying on experimental work, and these funds cannot be used or diverted to any other purpose. Practically all the lakes have experienced managers or custodians. Many are trained men who have nothing to do except study the specific needs of that particular reservoir. I understand that the same practice is followed in a great many other places. The important thing is that we draw the line where fishing would interfere in any way with the sanitary or domestic use of the water. 